Nicholai Studies, Vol. I, No. 1 (2021): 209-214.

DOI: https://doi.org/10.46825/nicholaistudies/ns.2021.1.1.209-214 UDC: 929-055.2(497.11)"1914/1918"(049.32)

Received: November $23^{\text {rd }}, 2020$. Accepted: December $22^{\text {nd }}, 2020$.

\title{
Slavica Popović Filipović, The Great Women in the Great War
}

Pančevo 2020, $761 \mathrm{pp}$.

[In Serbian: Slavica Popović Filipović, Velike žene u Velikom ratu. Biblioteka Hrestomatija [Mali Nemo]. Pančevo: Mali Nemo, 2020. 761 str.; ilustr.; $25 \mathrm{~cm}$. ISBN 978-86-7972-124-2]

Just released is a new book by Slavica Popović Filipović (known to English readers as Popovich Filipovich as well) entitled Great Women in the Great War. It is a major publication, of an impressive size, as the result of many years of research investigation in the areas of the history of the World War I, remembrance, history of medicine and medical corps, cultural diplomacy, history of the suffragette movement, humanitarian and philanthropic work. This book is the crowning glory of many years of research and publishing works of Mrs. Popovich Filipovich, who had previously already published a large number of research papers that encompassed the above topics.

This research project was an undertaking involving reviewing extensive archived materials, original documents, correspondence, hand-written texts, and photographs in various archives in different parts of the world, as well as in private family storage. The work in front of us is dedicated to some exceptional women who command exalted positions, women who sacrificed their personal lives by sharing wartime suffering with the Serbian people and armies during the trau- 
matic war years: the typhoid epidemics, the exodus through the Albanian mountain ranges, the exile on the island of Corfu, Corsica, North Africa, on the Russian Front, and in Dobruja. Thus, this book is a remarkable evidence of the dedicated affection and strenuous work of over 2000 women doctors, medical sisters, and nurses who served in the hospitals of the Serbian Red Cross Society, the Scottish Women's Hospitals, the hospitals of the Serbian Relief Fund (SRF) and other voluntary and humanitarian organizations, in Serbia itself, and in the exile - both during the Great War and afterwards.

Knowing that the place and role of women in the history of the World War I have been traditionally marginalised, as pointed out by the author in the Introduction (pp. 9-16), this book gives a significant contribution to our understanding of these exceptional women who willingly risked their own lives in order to help others in need.

Mrs. Popovich Filipovich has gathered valuable documentation about scores of outstanding women from the abovementioned number - about renown Serbian women, the first Serbian and foreign women doctors, British suffragettes, Scottish women, American, Australian and Canadian women humanists, writers, painters, journalists, titled Ladies, and heroines from across the Atlantic and the Pacific Oceans, each with her own chapter in this book.

Thus the readers will find in this book a humanist, teacher, and translator Ljubica Luković (1858-1915), who was President of the Serbian Women's Society "Kolo srpskih sestara" from 1905 until 1915 (pp. 17-54); Dr. Angelia Al. Yaksitch - Anđelija Jakšić (1871-1950), awarded the Order of St Sava, and the Medal Albanska spomenica (pp. 55-89); the Scottish Dr Elsie Maud Inglis (1864-1917), a doctor and surgeon, the founder and Head of the Scottish Women's Hospitals - SWH (pp. 91-136); Dr. Isabel Galloway Emslie, Lady Hutton (1887-1960), the Scottish doctor, awarded the Order of St Sava, and the Russian Order of St. Anna, volunteered in SWH in France, Gevgelia, Salonika, and in Vranje after the Liberation (pp. 137-173). 
Among those extraordinary ladies that are introduced to us in the book by Mrs Filipovich are: the Honorable Evelina Haverfield (1867-1920), a Baroness and a member of SWH in Serbia during the typhoid epidemic, and buried in the grounds of the St. Elijah Church in Bajina Bašta (pp. 175204); then a better known to the readers our renown woman painter and humanist Ms Nadežda Petrović (1874-1915), also awarded the Order of St Sava; Delfa Ivanić (1887-1972), the co-founder of "Kolo srpskih sestara" (pp. 229262); then the American Dr Rosalie Slaughter Morton (1876-1968), who was awarded numerous Serbian and foreign state and church medals and awards for her various achievements (pp. 263-290); then the British volunteer nurse in Serbia Dame Louise Margaret Lei-

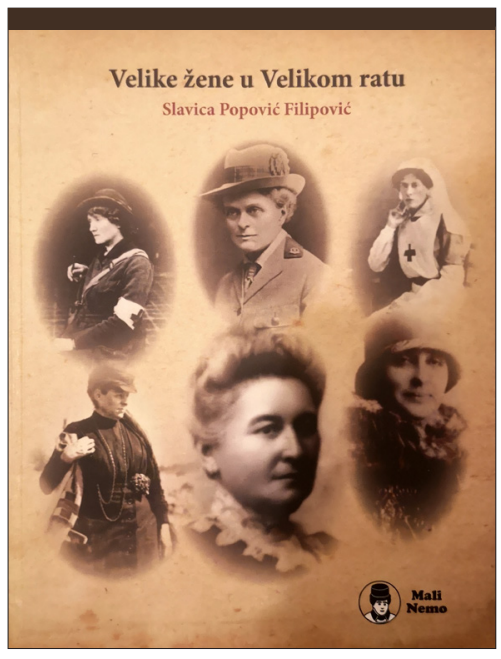
la Wemyss Paget - Lady Paget (1881-1958), who headed the First Unit of the Serbian Relief Fund, and was granted the First Grade of the Order of St. Sava (pp. 291-326); Mrs. Gertrude Carrington Wilde (1856-1945), a longtime member of the Serbian Relief Fund, in the mission for the Serbian people and Serbian children, a holder of the Second Grade of the Order of St. Sava (pp. 327-340), Mrs. Hannah Hankin Hardy (1866-1944), a volunteer nurse in Kragujevac, who collected and delivered a huge medical and humanitarian aid for the Serbian hospitals (pp. 341-357).

Following the previous books, the author continues to do research about Mrs. Jelena Lozanić Frotingham (1888-1872), a relief worker, and representative of the Serbian Red Cross in America and Canada, now with the special emphasis on a joint mission with Michael Pupin and John Frotingham (pp. 359-402); Australian from Sydney, Dr. Agnes Elizabeth Lloyd 
Bennett (1872-1960), the head of the Scottish Women's Hospital at the Salonica Front, who was granted the third grade of the Order of St. Sava (pp. 403-46o); a humanitarian worker, writer and translator Miss Lena Alexander Jovičić (18851969), a daughter of a Scottish lady Alice Mary Rutherford and Alexander Jovičić, a Serbian diplomat (pp. 461-494); the Brtitish suffragette, relief worker and the holder of the Order of St. Sava - Mrs. Mabel Annie St Clair Stobart (1862-1954), the head of the Third Unit of the Serbian Relief Fund in Kragujevac, who established seven dispensaries in the villages of Šmadija (pp. 495-544); and Miss Olive Kelso King (18851958), a member of the Scottish Women's hospital in France, Serbia and on the Salonica Front, but also known for her humanitarian work, was granted the Order of St Sava and other Serbian and international decorations (pp. 545-585).

The following chapter is about a volunteer nurse and philanthropist French Countess Marie de Shabannes la Palice (1890-1977), who helped Dr. Mihailo Petrović to establish the First Serbian Surgical Field Hospital on the Salonica Front (pp. 587-621); Madam Mabel Gordon-Dunlop Grouitch (1872-1956), an American humanist, and Serbian daughterin-law, promoter of the Serbian struggle in Europe and America (pp. 623-646); Russian noblewoman Mrs. Alexandra Pavlovna Hartwig (1863-1944), a humanist and volunteer nurse, who contributed to the formation of numerous Russian hospitals to help Serbia, personally delivered the medical mission Russian Pavilion in Niš (pp. 647-68o); and the Serbian doctor Dr. Slavka Mihajlović-Klisić (1888-1972), the only doctor at the Belgrade General Hospital after the Great Exodus, who left a diary of the Belgrade's suffering in the Great War (pp. 681-715); Canadian humanist and doctor Dr. Harriet Macmillan Cockburn (1873-1948), a doctor in the Third Unit of the Serbian Relief Fund in Kragujevac and the head of the dispensary in Lapovo, but also her colleagues from the homeland of the maple tree, who treated Serbian soldiers in Serbia and on the Salonica Front (pp. 717-743). 
From the introduction in Serbian and English, the book has 21 chapters, written on 761 pages, with each chapter having a summary in English (the translations were done by Bob Filipovich, NATI Fellow) extensive literature, and finally an index with hundreds of names (pp. 745-754), a note on the author, and her gratitude to numerous associates, friends, collaboration team, especially the reviewer Dr. Veljko Todorović, the translator Mr. Bob Filipovich, the editor-in-chief, Mr. Milan Orlić Ph.D., the book-cover designer, Ms Jelena Basta, the editors Mr. Duško Lopandić and Miss Danica M. Savić, and others.

This book is valuable for the researchers of the Serbian religious history in general, and also for the research into the personality and life and work of Bishop Nicholai Velimirovich in England, because this book documents his connection and cooperation with those heroines in the Great War, even at the time before he became a bishop, as well as with other Serbian Church dignitaries. Also in this book are presented personal diaries of Jelena Lozanić describing her meetings with Velimirovich in USA during 1915 (pp. 373-374), then about joint activities of Father Nicholai, Honourable Evelina Haverfield, Dr. Elsie Inglis, and other humanitarians in the Committee for the Serbian National Day "Vidovdan" ("Kossovo Day") celebrated in Great Britain in 1916 (pp. 190-191). The book also describes the support of Bishop Nicholai for the establishment of the First Nursing School in Belgrade in 1920 (pp. 702), and the mention of the lifelong friendship between Nicholai and Lady Paget (pp. 322) etc.

In the chapter about Lady Paget a special attention is given to her dedication and her care and help for other Serbian refugees, such as Dalmatian Bishop Irinej Đorđević (1894-1952), and Archpriest Miloje Nikolić (†1989), as well as her unselfish care and assistance to countless Serbian refugees for whom this lady spent all her property. In the end she even sold her family castle, a very valuable property that was owned by her family and ancestors from the time it was built in 1865. This philanthropic woman spent the last years of her life in a small 
cottage, having spent all her material goods and property for the welfare of others (pp. 322-323).

In this book are also collected and presented documents that exhibit the co-operation between other prominent religious personalities from the Serbian sacral history and those humanitarian women, who took care of the sick and wounded. One good example was Dositej Vasić (1878-1945), the wartime Bishop of Niš, who worked with Mrs. Hartvig and other humanitarians. The book also presents more information about philanthropic service to the needy, and humanitarian activities of persons from other denominations and churches, such as the Russian Medical Mission of Athonite Monks under Hieromonk Epiphanius (pp. 50, 667).

Though this book contains an Index of names, it is a great pity that some pages were not included (such as that of Nicholai Velimirovich, who was also mentioned on pages 323, 335, 374, 477 , etc., but these pages are not included in the Index). Also omitted are the names of Bishop Irinej Đorđević and Fr. Miloje Nikolić. However, these omissions are negligible compared to the wealth of information that this book brings to the Serbian readers and others. These are indeed valuable fruits of many years of laborious research by Slavica Popović Filipović. Therefore, we warmly welcome the publication of this book. 